\title{
Jhumpa Lahiri's the Lowland: A Critical Analysis
}

\author{
Dr. TK Pius \\ Associate Professor of English St. Aloysius College Elthuruth PO Thrissur, Kerala India- 680611
}

\begin{abstract}
Jhumpa Lahiri's novel The Lowland, traces the fate of tender fraternal bonds torn asunder by violent politics. Lahiri's delineation of the narrative events purports to show how the absence of loved ones becomes covertly a portent haunting presence within the subconscious mind of the affected characters directing their overt actions to their own consequential ways of life through which they are goaded on. When their respective paths crisscross, Lahiri proves herself to be adept at depicting the unhappiness at the core of the intricate interpersonal relations that materialises. This write-up attempts to grasp the import of this novel by situating the author's unique presence both in the post millennium Indian English fiction as well as in the fabric of the narrative. Its analytical method moves from an elaborate study of the tortuous plot through a network of characterisation, scrutiny of the multiplex narration leading to a medley of themes that have contemporary appeal.

Key Words: plot-characterisation - narrative technique - thematic dimensions
\end{abstract}

\section{Introduction}

Indian novelists are muscling into the ranks of top English-language writers, making their way onto the best-seller lists and snapping up a disproportionate share of the literary awards. Names such as Anita Desai, Arundhati Roy, Amitav Ghosh, Vikram Chandra, Kiran Desai, Aravind Adiga, and Salman Rushdie are just those who come to the minds of the readers without effort. Within this pantheon of literary achievers, the Indian-American writer Jhumpa Lahiri fits comfortably. Lahiri first made her name with the quiet, meticulously observed stories about Indian immigrants trying to adjust to new lives in the United States, stories that had the hushed intimacy of chamber music. Navigating between the Indian traditions they have inherited and the baffling new world, the characters in the first collection of short stories entitled The Interpreter of Maladies, (1999) which won the 2000 Pulitzer Prize for Fiction, seek love beyond the barriers of culture and generations. In her first novel, The Namesake (2003) which was made into a popular film, Lahiri enriches the themes that made her first collection an international bestseller: the immigrant experience, the clash of cultures, the conflicts of assimilation, and, most poignantly, the tangled ties between generations. Here again Lahiri displays her deft touch for the perfect detail - the fleeting moment, the turn of phrase - that opens whole worlds of emotion. Then the eight stories which appeared in Unaccustomed Earth (2008) take us from Cambridge and Seattle to India and Thailand, as they explore the secrets at the heart of family life. Here they enter the worlds of sisters and brothers, fathers and mothers, daughters and sons, friends and lovers. The Lowland is Lahiri's fourth book. It was shortlisted for the National Book Award in 2013, the Man Booker Prize 2013 and the Bailey's Women's Prize for Fiction 2014. She was inducted into the American Academy of Arts and Letters in 2012.

\section{Context}

The Lowland is similar to the other works that Lahiri has written: beautiful, sparse accounts of people lost in new worlds. The reader is always struck by how she writes about the particulars of feeling strange: for instance, the bated breath of watching one's children grow up in a world so terribly different from one. Thematically considering her book, one feels there is a strong sense of the immigrant with this book like Gary Shteyngart's Little Failure: A Memoir, (Shteyngart) published, thirty-five years after Gary emigrated to the U.S. Her writing is an outflow of her own life, born to Bengali parents, raised on the East Coast of India. As one has learnt to expect from any Lahiri novel, The Lowland revolves around a Bengali immigrant family in the United States (the Mitras) and the Indian sections serve as a background to the story as it develops. Yet, placing the book in the category of "immigrant fiction" does not sit well with Lahiri as she stated in an interview, "It just so happens that many writers originate from different parts of the world than the ones they end up living in, either by choice or by necessity or by circumstance, and therefore, write about those experiences."(Mayfield) in literature and that many a native has written about the poles of alienation and assimilation. While she may set some of her scenes in India or elsewhere, her themes are universal.

Lahiri says the book is based on a tragic incident she first heard about in India, during one of her many visits while she was growing up. Two young brothers, who had become involved in a violent political movement, were executed just a few hundred yards from her grandparents' home in Calcutta. The young men's family was forced to watch as they were killed."That was the scene that, when I first heard of it, when it was 
described to me, was so troubling and so haunted me - and ultimately inspired me to write the book," Lahiri says. ( Neary) The Lowland has been considered as a story about two brothers, but it could easily be the story of ideology, and how it shapes the family. The descriptions of the world the boys were born into are vivid without catering to our thirst for the exotic. The characters here are middle-class, living in a quiet subdivision, focused on thick textbooks and transistor radios, on sneaking into the club for foreigners right outside their doors. As the boys grow older and their interests take different paths, changing the lives of everyone around them, we see India fade into the background and the bleak solitude of New England academia takes over.

\section{Title}

The book begins with the description of lowland itself, lowland that was to be a monumental place for the Mitras in the future. The opening lines reads like the way one would guide a new traveller to reach the place: "East of the Tolly Club, after Deshapram Sashmal splits in two, there is a small mosque. A turn leads to a quite enclave. A warren of narrow lanes and modest middle-class homes. Once within the enclave, there were two ponds, oblong, side by side. Behind them was the lowland spanning a few acres."(3)

Geography is destiny in The Lowland. Her title refers to a marshy stretch of land between two ponds in a Calcutta neighbourhood where two very close brothers grow up and where one of them is killed. In monsoon season, the marsh floods and the ponds combine; in summer, the floodwater evaporates. The reader doesn't need any decoder ring to figure out that the two ponds symbolize the two brothers - at times separate; at other times inseparable. But there is still more meaning lurking in this rich landscape. The features of the lowland given deft matter-of-fact strokes have a telling impact on the characters of the novel. Lahiri's narrator goes on to tell us: "Certain creatures laid eggs that were able to endure the dry season. Others survived by burying themselves in mud, simulating death, waiting for the return of rain." (3) In the suburban streets of Calcutta where the two brothers wandered before dusk and in the hyacinth-strewn ponds where they played for hours on end, the lowland was their playground.

For most of Lahiri's novel, we are stuck in the mud with the cautious older brother whose name is Subhash. Consequently, there is a quality of stillness to The Lowland that, especially in its opening sections, almost verges on the stagnant — or would, were it not for Lahiri's always surprising language and plotting. The Lowland is something of a departure for Lahiri, whose other work often explores the struggles of Indian immigrant families. The Lowland, instead, opens in Calcutta in the 1950s and '60s, and keeps returning there even as the main story moves ahead in time.

\section{Setting and Time}

The Lowland is a multi-generational tale that stretches almost five decades set in Tollygunge and Rhode Island. Tollygunge assumed significance during the time of the British East India Company: "In the early nineteenth century, on Johnson's estate, the British East India Company imprisoned the widows and sons of Tipu Sultan, the ruler of Mysore, after Tipu was killed in the Fourth Anglo Mysore War... After their release, they were granted plots in Tollygunge to live on. And as the English began to shift back to the centre of Calcutta, Tollygunge became a predominantly Muslim town." (13) And Rhode Island is a small state within the context of America with "mountains to the north, an ocean to the east, majority of land to the south and west"(35) On one level, The Lowland reflects two sides of its author's persona - her Bengali heritage (though she was born in the UK) and her upbringing in Rhode Island. The novel's action is divided between the middleclass precincts of Calcutta and the academic world of Rhode Island. The plot revolves around two momentous incidents, one taking place in Kolkata in 1971, the other in Rhode Island twelve years later.

The readers of the novel don't have to be in a certain place, at a certain time to be able to catch the faint thrum of the lifeblood coursing through the pages of this book, to live the heartbreak of its characters, to develop a sense of solidarity with their loss and desperation, to gaze at the spectacle of their unravelling fates across continents. But it will help them if they have lived, at some point in time, in a city christened Calcutta by the British and rechristened Kolkata (the pure Bengali name) centuries later by a government intent on erasing telling signs of a nation's unfortunate colonial past. It will help if they have ever felt rudderless, adrift in a sea of anonymous human faces, unable to come to terms with a painful event, its aftermath too profound and terrible for readers to grasp at once. It will help if they are carrying on with a half-life thousands of miles away from the land of their birth, toeing the line of divide between two distinct yet similar worlds.

In the novel Lahiri has brought the humble, modest, Tollygunge to life. This decrepit and majestic city has been witness to the rise and decline of too many political regimes, to the bloodletting during senseless communal riots and a terrible famine manufactured by a colonial administration too busy fighting a world war. Tollygunge has been immortalised in the novel, living for centuries, like a mythical, gargantuan beast and it would continue to throb with life and activity years to come. Lahiri intends to show how silly is that in our eagerness to match steps with the developed world, to achieve set targets, we forget the blood-soaked, tearstreaked history of the country we live in, that we are inextricably bound to the political upheavals which serve 
as foundation stones to our present state of equanimity, to the sheer tragedy and violence of turbulent times. With The Lowland, Lahiri has achieved something monumental, in that it is successful in rekindling an extinguished flame within the readers, through an accurate enactment of that unmistakable sensation of being anchored to a place and a way of life, of being pulled towards a powerful centre.

Lahiri gently propels readers towards a life-like portrait of Calcutta, , the maddening, mystifying, glorious and ugly city which will remain the beloved in the course of their reading experience, towards the people who inhabit its upscale townships and dingy shanties, towards the unknown stories of hardship and triumph which breathe life into this jungle of steel, brick and mortar, towards the struggles of an ill-fated generation now forgotten in the mad dash for globalization, towards a culture which has moulded generations into what they are today. Regardless of where her readers may have grown up - Rhode Island or Tollygunge irrespective of whichever movement has left its indelible mark on the socio-political landscape of the nation SDS or Naxalite agitation - Lahiri will take her readers on a trip down memory lane, back to their roots, to the values that reside at the core of themselves and hold them together, to the people they have left behind somewhere in this long, befuddling journey of life but cannot ever forget. And she may remind them of who they used to be once and what they are now.

\section{Plot}

When one senses characters, when the plot of a novel doesn't stray but goes forward with such purpose, all that one needs to do is to follow what unfolds in the subsequent pages of the book. The Lowland is buoyantly ambitious in both its story and its form. From the first line onwards this book is just a magic recreated with a delightful and mesmerising penmanship. There is no relief in the storyline; it strangles you with one tragedy after the other and this might remind the reader of Hosseini's And the Mountains Echoed (2013). Commenting on his novel, Hosseini said: " My new novel is a multi-generational family story ... revolving around brothers and sisters, and the ways in which they love, wound, betray, honour, and sacrifice for each other." (Driscoll) Like Hosseini, Lahiri plays with the relations, breaks them, shapes them, recreates them and she does that with sheer command over the language.

Sketched in Bengali blood, The Lowland is a tale of two Bengali brothers preternaturally closes in their youth, who forge very different paths for themselves as they grow up in Calcutta during the 1950s and 60s. They look and sound alike but are very different from each other. When the novel begins, "Subhash was thirteen, older by fifteen months. But he had no sense of himself without Udayan. From his early memories, at every point, his brother was there." (6) Subhash has shown himself to be very cautious from his early childhood and his favourite moments were when he alone preferred to live in his own world. Their relatives at large gatherings sometimes said, "While Subhash stayed in clear view, Udayan was disappearing: even in their two-room house". (10) When he was a boy, Udayan hid compulsively, under the bed, behind the doors, in the crate where winter quilts were stored. He played this game without announcing it, spontaneously vanishing; forcing their mother, to stop what she was doing to seek him out. When they were old enough, they were permitted to leave the house but were asked "not to lose sight of one another". (10) They were also taught to honour their parents and observe the old customs. While Subhash jelled wonderfully with his ambient, Udayan, the more daredevil brother, was always in search of new pastures. Subhash, in contrast, dutifully dedicated himself to personal, rather than collective, improvement. The readers are shown much mundane details about their day-to-day lives to let them conclude that the two brothers, close in age, were very different - one, angry, restless, protesting corruption, but also selfish, impulsive; the other, static, taking the easier road, detached, settled in his own loneliness - and that they remained different; they didn't change or learn or grow or develop as human beings, and their motivations for doing anything was felt thrice-removed.

Yet, in spite of their differences one was perfectly confused with the other, so that when either name was called both were conditioned to answer and sometimes it was difficult to know who had answered, given that their voices were nearly indistinguishable. They were similar enough in build to draw from a single pile of clothes. Their complexions, a light coppery compound derived from their parents, were identical. Subhash, is a passive conformist who has pre-defined limits that adhere to the laws of society. Subhash's conduct is contrary to that of Udayan's, who loves to take risks and challenge the conventional, and compared to whom Subhash considers himself inferior. "Subhash wondered if his placid nature was regarded as a lack of inventiveness, perhaps even a failing, in his parents' eyes. His parents did not have to worry about him and yet they did not favour him. It became his mission to obey them, given that it wasn't possible to surprise or impress them. That was what Udayan did" (11)

After their successful school years, they were admitted to two of the city's best colleges -Udayan would go to Presidency to study Physics and Subhash, for chemical engineering to Jadavpur. They had their unique preferences in matters of study or play. When asked by their parents what they wanted as a gift, to acknowledge their achievements, Subhash suggested a marble chess set to replace the worn wooden pieces they'd always had. 
But Udayan wanted a shortwave radio. He wanted more news of the world than what came through their parents' old valve radio.

In 1967, in the papers and on All India Radio, they started hearing about Naxalbari, one of the strings of villages in the Darjeeeling District, "a narrow corridor at the northern tip of West Bengal. Tucked into the foot-hills of the Himalayas, nearly four hundred miles from Calcutta, closer to Tibet than Tollygunge." (20) Most of the villagers were tribal peasants who worked on tea plantations. For generations they had lived under the feudal system. They were preyed upon by moneylenders, manipulated by wealthy land owners, deprived of subsistence wages, pushed off fields they had cultivated, and denied revenue from crops they had grown. When a sharecropper in Naxalbari tried to plough the land from which he had been illegally evicted, his landlord sent thugs to beat him up and loot his belongings. After this, groups of sharecroppers began retaliating armed with primitive weapons, carrying red flags, shouting "Long Live Mao Tse-tung".(20) They started burning deeds and records that cheated them. The Government authorized about five hundred officers to raid the region. "They searched the mud huts of the poorest villagers. They captured unarmed insurgents, killing them if they refused to surrender. Ruthlessly, systematically, they brought the rebellion to its heels." (22)

Both the brothers were speechless and shocked when they heard over the radio how the government arbitrarily brought the rebellion to its end. Udayan, by nature a dynamic idealist, charismatic and impulsive, finds himself propelled by social conscience into the Naxalite movement, a rebellion waged to eradicate inequity and poverty; he will give everything, risk all, for what he believes. He was affected so much by the police action against the sharecroppers that he was reacting as if it were a personal affront: "People are starving and this is their solution, he eventually said. They turn victims into criminals. They aim guns at people who can't shoot back... This could only be the beginning of ... Something bigger. Something else." (23) True to the spirit of the movement, Udayan, becomes convinced that he should set himself on to better the living conditions of India's poor through violent uprising.

When their father sensed the danger of Udayan's deep emotional involvement in the movement, he accusingly admonished them: " I've already lived through change in this country, ... I know what it takes for one system to replace another. Not you." (23-4) But Udayan persisted, challenging their father, in a way he used to challenge teachers at school. He started reading pamphlets written by Charu Majumdar who said India has turned into nation of beggars and foreigners. The reactionary government of India had adopted the tactics of killing the masses; they are killing them through starvation, with bullets." (24) Lahiri says at an interview, "Udayan and his comrades are "basically kids... I mean, they're college students. And so one can see how a certain ideology can be very attractive, and appear to be the solution, and appear to be the key to solving an enormous problem in a country and a society." (Neary)

His vision of life and reality was born anew in the new ideology of the Naxalbari movement so much so that if he happened to pass through the Tolly Club - where he had once sneaked in to play golf - on his way to or from the tram depot, Udayan called it an affront." People still filled slums all over the city; children were born and raised on the streets. Why were a hundred acres walled off for the enjoyment of a few?" (25) Udayan now considers golf as "the pastime of the comprador bourgeoisie."(25) He said that Tolly Club was a proof that India was still a semi-colonial country, behaving as if the British had never left the place. He used to be out for meetings in a neighbourhood in North Calcutta, to hear a wispy-haired medical student named Sinha, who asserted with emphasis: " If history is to take a step forward, the parlour game of parliamentary politics must end" (27) But Subhash was never convinced that an imported ideology could solve India's problems. Yet Subhash often went with his brother because " He was sick of the fear that always rose in him: that he would cease to exist, that he and Udayan cease to be brothers, were Subhash were to resist him". (30) Yet all these hectic activities and rampant student boycotts and unrest against prevailing system going on did not prevent them from pursuing their studies: both brothers began postgraduate studies, Udayan at Calcutta University, Subhash continuing at Jadavpur. After their studies ended, Subhash and Udayan found themselves among so many others of his generation, overqualified and unemployed. Udayan turns to radical politics because of the injustice and poverty he sees around him. But the more Udayan becomes involved in politics, the more Subhash feels alienated from him.

Subhash decided to apply for a few Ph.D. programmes in the United States while Udayan thought that by such a decision Subhash was being quite irresponsible to the issues of people. He said quite thoughtfully, " How can you walk away from what's happening? There, of all places?" (30) It is quite characteristic of him to impose his notion of social ethics on others particularly on Subhash. Here the reader will find Subhash retaliating in the same coin posing a few questions to Udayan: "This isn't a game you're playing. What if the police come to the house? What if you get arrested? What would Ma and Baba think? ... They're people who raised you. Who continue to feed and clothe you? You amount to nothing, if it weren't for them. "(30) Though Udayan got flared up initially, he comes to acknowledge the worth of his gracious presence for the first time in his life: "You're the other side of me, Subhash. It's without you that I'm nothing. Don't go. It was the only time he'd admitted such a thing. He'd said it with love in his voice. With need." (31) 
On Lenin's birthday, April 22, 1969, a third communist party named the Communist Party of India, Marxist-Leninist was launched in Calcutta with Charu Majumdar as the general secretary, and Kanu Sanyal, the party chairman. The members called themselves Naxalites, in honour of what had happened at Naxalbari. "The chief task of the new party was to organise the peasantry. The tactic would be guerrilla warfare. The enemy was the Indian state." (33) In the rally that was held to mark the day, Sanyal said, "We will certainly be able to make a new sun and a new moon shine in the sky of our great motherland" (33). The news papers published photographs of the huge crowd who gathered to hear Sanyal's speech announcing the birth of a new communist party - CPM(ML). The narrator records what might have passed through the mind of Subhash as he glanced through these photographs: " It was a portrait of a city Subhash no longer felt part of. A city on the brink of something; a city he was preparing to leave behind. Subhash knew Udayan had been there. He hadn't accompanied him to the rally, nor had Udayan asked him to come. In this sense they had already parted." (33). Speaking about the contrast in the character traits of the two brothers, Lahiri said, "I thought it would be much more interesting for the story to set up a contrast between these two brothers, to have one involved politically and one to be aloof, because I think it creates an inherent tension between the brothers,...And I wanted to show how the movement could seduce one while leave another indifferent." (Neary)

Subhash's dream of doing $\mathrm{PhD}$ in America is soon materialised when he gets a scholarship to settle in Rhode Island (where Lahiri grew up) for his research. He thus steps out of Tollygunge "as he had stepped so many mornings out of dream, its reality and its particular logic rendered meaningless in the light of day". (34) Life in Rhode Island was entirely different. He breathed a sense of freedom because unlike his days in Tollygunge, life ceased to obstruct or assault him. "Here was a place where humanity was not always pushing, rushing, running as if with a fire at its back" (34) He lived at the top of a house, sharing a kitchen and bathroom with another PhD student named Richard Grifalconi, a student of sociology. Subhash learned to settle down quietly without joining in any of the student protests against the government's policies on Vietnam. He knew "he'd been invited to America as Nixon's guest... He knew that the door could close just as arbitrarily as it had opened. He knew that he could be sent back to where he'd come from, and that there would be plenty to take his place" (36) For a couple of lonely years in a student boarding house, he learns to live without the voices of his family. He was in a sense proud to have come to America alone to study oceanography. Soon he learned to live here "as he once must have learned to stand and walk and speak. He'd wanted so much to leave Calcutta, not only for the sake of education but also -- he could admit this to himself now-- to take a step Udayan never would. " (40) Yet his motivation had done little to prepare him. He felt quite uncertain though he was happy to escape from a city he sees disorganised and violent. "Here in this place surrounded by sea, he was drifting far from his point of origin. Here, detached from Udayan, he was ignorant of so many things." (40) He found in the beaches of Rhode Island a resemblance to the delta lowlands surrounding Calcutta and he learned to live by this association with his homeland.

Subhash soon receives a letter from Udayan. He felt their loyalty to one another once more, their affection stretched half way across the world. Yet, "stretched to the breaking point by all that now stood between them" (43) Udayan hoped that Subhash, after his studies would come back to "an altered country, a more just society".(42) The final lines of the letter was almost melodramatic and indicated the place of Subhash in his life. "The days are dull without you. And although I refuse to forgive you for not supporting a movement that will only improve the lives of millions of people, I hope you can forgive me for giving you a hard time. Will you hurry up with whatever you are doing? An embrace from your brother" (42-3). The second letter informed him of his marriage to Gauri, who was doing a degree in Philosophy at Presidency. She was a girl from North Calcutta, Cornwallis street, whose parents were dead and who lives with her only brother Manash. And Manash had befriended Udayan at Calcutta University, where they were both graduate students in the Physics Department. To Subhash, this was another instance of Udayan forging ahead of him and of getting on his way."Not only had Udayan married before Subhash, he'd married a woman of his choosing. On his own he'd taken a step that Subhash believed was their parents' place to decide" (47) Udayan had sent him a photograph of Gauri as a proof of what he had done. Once more Subhash felt "defeated by Udayan" for having found a girl all by him.

In the second year of his Ph.D. Subhash lived on his own because Richard had found a teaching job in Chicago. Though he used to receive a few letters from Udayan, he no longer referred to Naxalbari or to his political activities. He wondered what was happening in Calcutta and what Udayan might be masking. He also wondered if Gauri had replaced him in his house. During this time, he had a short relationship with a thirty-six year old American woman named Holly who lived with her son Joshua, separated from her husband, Keith. When Holly suddenly decided to get back to a life with her estranged husband, his life with her ended abruptly. Subhash began his third autumn in Rhode Island and he was reminded of the days of pooja in Calcutta. But quite unlike the other two years, he did not receive any parcel; instead he received a telegram which said, "Udayan killed, Come back if you can" (83) 
When Subhash managed to reach Calcutta, he expected his parents at the station to welcome him. There was only the younger cousin of his father's, Biren Kaka and his wife who had come to receive him at the station. Subhash recalled how Udayan had bid him farewell at the same station when he left for Rhode Island and the promise of his mother that he would receive a "hero's welcome"(88) when he would return from the US. During the train journey from Delhi to Calcutta, he had learned about the atrocious crimes of the Naxalites which were sadistic, gruesome and intended to shock. The old law which had been created by the British, to counter independence had been reinstated by the government. These laws authorised the police to enter homes without warrant, and to arrest young men without charges.

On reaching home, Subhash met his parents. Their faces conveyed disappointment, "calloused by grief, blunted by what no parent should have seen"(91). Subhash stood before the image of Udayan and wept. Soon he came to understand that his parents received Gauri coldly and treated her badly because the marriage was not an arranged one. He also learned that she was expecting Udayan's child. His parents refused to talk to her or acknowledge her presence in the house. After lunch he went out, walking past the two ponds. He noticed a small stone marker on which was written Udayan's name with the years of his birth and death, 1945-1971, inscribed on it. It was a memorial tablet, erected for political martyrs. His efforts to make his parents talk resulted in a bare few broken phrases. They did not ask him any news about Rhode Island nor asked him to stay back in Calcutta and abandon his studies abroad. They were in no position to plan his wedding or to think about his future. "The shared quiet fell over them, binding them more quietly than any conversation could." (96)

His parents felt uneasy to talk about Udayan's death. It was from Gauri that he could gather what actually took place on that fateful day. She described to him briefly how "she and his parents had watched Udayan die".(113) It happened a week before Durga Pujo in the month of Ashvin. Gauri and his mother were returning from a day of shopping with packets containing gifts for the extended family. When they reached their house, they found that policemen and soldiers were stationed in and around the house. Gauri saw her father-inlaw descending the stairs, his hands raised over his head with a policeman pointing a rifle at his back. Then Gauri and his parents were ordered to exit the house, forming a row. The police told them they were under orders to locate and arrest Udayan Mitra. Soon they spotted Udayan hiding behind the water hyacinth, in the flooded water of the lowland. The police announced over the megaphone that they were prepared to eliminate the family members if he did not surrender. Presently Udayan surrendered. His hands were bound; he was pushed into the police van. They took him to the damp grass that edged the lowland and shot him dead. They dragged his body by the legs and tossed him into the back of the van and drove away. The body was not returned to their parents. The police had discovered a diary in their bedroom which contained all the proof they needed.

They observed a mourning period of eleven days, at the end of which, a priest came for the final rites and a cook to prepare the ceremonial meal. Gauri was given a white sari to wear in place of coloured ones, so that she resembled the other widows who were three times her age in the family. She knew that "in less than nine months a baby would come. But its life had already been started, its heart already beating, represented by a separate line creeping forward. She saw Udayan's life, no longer accompanying her own as she'd assumed it would, but ceasing in October 1971. This formed a grave in her mind's eye... She wished the days and months ahead of her would end... And yet somehow she was breathing. Just as time stood still but was also passing, some other part of her body that she was unaware of was now drawing oxygen, forcing her to stay alive." (111) Subash' s parents did not want her, they only wanted her child. They often repeated to her, "You won't be of help" (110) His mother said she could choose to go somewhere to continue her studies. Subhash pleaded for her saying, "You can't separate them. For Udayan's sake, accept her" (114) His mother was very angry and she spoke in an insulting tone: "Don't tell me how to honour my own son".(114)

Piecing together the various data he had garnered, he soon came to the conclusion that Udayan had given his life to a misguided movement that had already been dismantled. The only thing he had altered was what their family had been. His parents had been lenient regarding Udayan, as they had always been. He had kept Subhash deliberately in the dark as he went on clandestinely, putting together bombs, blowing up things. Gauri was the only one he had trusted. He had inducted her into their lives only to strand her there. There was nothing Subhash could do to console his parents. It had mattered little if he had come all the way from Rhode Island at all. His mother's deliberate coldness toward Gauri, reinforced by his father's passivity was intended to drive her away from the house. All he could do to help Gauri from the cruelties of his parents and the frequent police inquiries was to take her away legally by marrying her: "To take his brother's place, to raise his child, to come to love Gauri as Udayan had." (115). Subhash knew only too well that even if the police were to leave her alone, his parents would not. Subhash tried to convince her of the most obvious facts: "that in America no one knew about the movement, no one would bother her. She could go on with her studies. It would be an opportunity to begin again". (119) Giving due consideration to what Subhash suggested to her, Gauri decides to accompany Subhash to Rhode Island, not the least out of any love she felt for Subhash, but it offered an alternative for change and academic prospects which she longed for. 
She observed that two obvious facts reminded her of Udayan's presence. The first was the voice of Subhash: "Almost the exact pitch and manner of speaking. This was the deepest and most startling proof of their fraternity. For a moment she allowed this isolated aspect of Udayan , preserved and replicated in Subhash's throat, to travel back to her" (122) The second and most unavoidable fact was that she was carrying Udayan's child: " She felt as if she contained a ghost, as Udayan was. The child was a version of him, in that it was both present and absent. Both within her and remote" (124) She was beset by many irrational fears of the child forming within her: "she'd momentarily feared that the child would dissolve and abandon her" (124)

Her life had always been stretched to the extremities by choice or circumstances. While her elder sisters led a normal life with her parents, she was brought up in her grandparents' house and she felt a sense of autonomy. Later, she had felt audacious eloping with Udayan, flaunting conventions. With Udayan's death, she felt, the ligaments that had held her life together had perished. Now her impulsive and calculated decision to be Subhash's wife, to flee to America with him, and with that action also to flee from Tollygunge, to forget everything her life had been, she felt even more extreme. When Udayan was killed, Subhash's mother had lashed out that Udayan would not have been killed had he married another sort of girl. Now her second marriage to Subhash, she considers it most unchaste because she was expected to honour Udayan's memory and his martyrdom. Besides, she did not want a girl in her family, "to become her daughter-in-law twice over ". (186) She had warned Subhash that he was risking everything. She had forbidden Subhash and Gauri never to enter the house as husband and wife.

But Gauri had married Subhash also as a means of staying connected to Udayan. "In the back of her mind she told herself she could come one day to love him, out of gratitude if nothing else." (127). But even as she was going through this phase of her life, she knew it was useless, "just as it is useless to save a single earring when the other half of the pair was lost" (128) In Rhode Island, she was not receptive to Subhash either; she continued to maintain the distance and her independence from him. She was unable to express her gratitude for what he had undertaken or to convey the ways he was a better person than Udayan. They lived separately in the same apartment. All the while Subhash hoped things would be different in the course of time. He felt, "he had inherited his brother's wife; in summer he would inherit his child" (141)

Initially she tried to mingle with the mixed Indian community: for instance, she was happy to mix with other women of the University at the dinner party of Narasimhan and Kate. Later she withdrew saying she did not have anything common with them. Subhash found it quite disturbing when she cut her hair short , dramatically altering her face and adopted the American style of dressing. Certain irrational fears haunted Gauri before and after the birth of Bela, her child. After Bela was born, Gauri was aware "how the slightest oversight on her part could cause Bela to be destroyed". (145) She felt Bela was her child and Udayan's, and Subhash for his helpfulness was simply playing a part. But soon Bela seemed to recognise Subhash: "To accept him, and to allow him to ignore the reality that he was an uncle". (146) As the years passed Gauri is found to be withdrawing little by little from her role as a mother, contrary to the position she had naturally asserted earlier stating, "I'm her mother".(146) On the other hand, Subhash, who according to Gauri was just role playing, strives to achieve the implication of his promise to Gauri, "I'll make it [Bela] mine, Gauri" (137).

After Bela began to go to school, Gauri spent her time at the University library on Philosophy. Her readings and ruminations on the concept of time in the context of her own future haunted her but they also kept her alive: "it remained her sustenance and also her predator". (151) Most people lived wilfully anticipating future and the narrator delves into its significance in the life of the major characters: "Her [Gauri's] in-laws had expected Subhash and Udayan to grow old in the house they had built for them. They had wanted Subhash to return to Tollygunge and marry someone else. Udayan had given his life for the future, expecting the society itself to change. Gauri had expected to stay married to him, not for less than two years but always. In Rhode Island, Subhash was expecting him Gauri and Bela. For Gauri to be a mother to Bela, and to remain a wife to him" (152) Gauri received some occasional letters from Manash which she resisted reading, given what they reminded her of. A part of Gauri still continued to expect illusorily some news from Udayan. "For him to acknowledge Bela, and the family they might have been. At the very least to acknowledge that their lives, aware of him, unaware of him, had gone on" (154)

The paternal instinct in Subhash was sublimated, when he observed that in his presence there was such a liberal outpouring of who Bela really was. At Bela's insistance, Subhash used to lie beside her until she fell asleep. It was a reminder of his paternal connection which overwhelmed him, a connection at once true and false. Sometimes Bela would hold his face in her hands and ask him:

Do you love me?

Yes, Bela.

I love you more.

More than what? 
I love you more than you love me.

That's impossible. That's my job.

But I love you more than anybody loves anybody. (156)

Subhash wondered how such powerful emotions as this could emanate from within a small child. Each night getting out of her bed, after she has fallen asleep, he wondered what she might say, the day she learned the truth about him. However, the fatherly tenderness Subhash felt for Bela, was not the same on Gauri's end. Though she cared for Bela capably, she seemed quite distracted. Bela was quick to observe this: "You're not paying attention, Bela protested, when Gauri's mind strayed".(161) She behaved "as if she'd reversed their roles, as if Bela were a relative's child and not her own". (159) Subhash had even gone to the extent of suggesting that Gauri would think of having a child with him to give Bela a companion. If they were four instead of three, he believed, it would close up the distance and correct the imbalance. Though Subhash was right from his own point of view, she would never risk no such compromises; "that though she had become a wife a second time, becoming a mother again was the one thing in her life she was determined to prevent from happening". (161) With Subhash she learned that sexual union intended to express love could have nothing to do with it; that her heart and her body were different things.

One day she asked Subhash if they could hire a babysitter to give her time to take a survey of German philosophy. Subhash did not agree to this on principle because he did not want to pay a stranger to care for Bela. He reminded her that her first priority under the present circumstances should be Bela and not her studies. But she begrudged Subhash's absence when he was at work and resented the few moments of the morning he enjoyed with Bela. "She was failing at something every other woman on earth did without trying. That should not have proved a struggle."(164) In her moments of distraction, she was angry at Udayan "for dying when he might have lived. For bringing her happiness, and then taking it away. For believing in sacrifice, only to be selfish in the end" (164)

Gauri often left Bela alone leaving her engaged while she took a walk alone. When Subhash found this out he told her, "My mother was right. You don't deserve to be a parent. The privilege was wasted on you."(175). Here Subhash was just connecting what his mother had warned him when he had almost planned an alliance between Gauri and him: "She's Udayan's wife, she'll never love you" (160) and that "She's too withdrawn, too aloof to be a mother" (114). The possibility of separating was not discussed since the point of their marriage was Bela. Gauri had never recognised the joy in sacrifice that motherhood always offered. Her professor Otto Weiss had offered her the requisite assistance to get her into the doctoral programme and she was looking forward to this.

In Tollygunge, Bijoli made it part of her routine to wash the memorial tablet erected by the party members in honour of Udayan's martyrdom, placing the flowers on it each day. She recalled how Udayan went about doing little acts of charity: he would collect worn out items, old bedding and pots and pans, to distribute to families living in slums; he would do the needful to bring a doctor to the poorest ailing sections of society; and so on. After Subhash's father retired from service, he spent his days reading books. The house stood practically empty. It has turned out to be a "mockery of the future they'd assumed would unfold" (181). Udayan has not lived to inherit it, and Subhash refuses to come back. At times, Subhash's father suggested selling the house and moving away from Tollygunge. But it wasn't possible for Bijoli to leave the house where Udayan had lived. A few days later when Deepa, the servant girl went into his room to give Mr. Mitra a cup $f$ tea, she found him dead in his sleep. Now Bijoli has become a widow, adding to the deepest sense of loss and shame, she had always felt with Udayan's death and more so by losing Subhash, still living away from her. It might have been because she was unable to love one without the other or because Subhash remained a spare version of Udayan and reminded her of the loss. With his father's death, Subhash is obliged to face Bijoli once more.

During one of those days after the death of her husband, she took a walk to the memorial stone. It was heaped with the leftovers of a marriage party. "She wants to know who has done this. Who has desecrated this place? Who has insulted Udayan's memory this way?" (190) She went slightly deranged of mind. She shouted at the neighbours and asked them if they have forgotten his martyrdom. Then pathetically she began to re-enact a reworked version of what took place in the final moments of Udayan. "Come forward, she calls out to those who are watching from their windows, their rooftops. She remembers the voice of the paramilitary, speaking through the megaphone. Walk slowly. Show your face to me. She waits for Udayan to appear amid the water hyacinth and walk towards her. It is safe now, she tells him. The police have gone. No one will take you away. Come quickly to the house. You must be hungry... Your brother has married Gauri. I am alone now. You have a 
daughter in America. Your father has died. She waits, certain that he is there, that he hears what she tells him".(190) Presently Deepa appears and coaxes her away to the house.

Subhash along with Bela came to Calcutta three months after his father's death. During the six weeks he would be there, he has planned a few lectures to be delivered in the nearby universities. The day after they arrived, Subhash sat for a ceremony to honour the demise of his father. Bela quickly got acquainted with her grandmother and Deepa. In the course of her stay, Bela came to know about Udayan, not as her father but as her uncle. She spent the afternoon of her twelfth birthday happily at Tolly club, though she felt the absence of her mother. After their planned period of stay at Tollygunge ended, they flew back to Rhode Island.

When they reached their house, they were in for a shock: Gauri left the place for good to California leaving a farewell letter on the table. She had accepted a teaching position in a college just to get out of the mess she was in, exposing "only her self-interest, her ineptitude... She'd done it, the worst thing that she could think of doing."(232) She was also quite indifferent if they should be in touch with one another. Reading the letter he was prepared to quell Bela's shock. But it was she who comforted him, holding him tightly, as if he would float away from her otherwise." I will never go away from you Baba, she said." 212) At the same time, Bela intensely felt her absence which Subhash's exclusive fatherhood could in no way compensate. Gauri's absence led to certain observable changes in Bela's behaviour. She performed badly at school and Subhash was asked to seek the help of Dr. Emily Grant, the psychologist. But soon her grades improved and apparently she seemed to be getting back her earlier self after she was promoted to the eighth grade. The year she graduated from school, Subhash received news from Deepa that Bijoli suffered a stroke. Since Bela preferred to remain at Rhode Island, Subhash flew back to Tollygunge alone to be beside Bijoly in her final hours. By the time he reached, she had died on her own in the hospital denying him the opportunity to watch her pass.

For her further studies, Bela chose a small liberal arts school in the Midwest. She did not want to spend her life inside the university researching things like her parents. It was the closest she came to rejecting how both Subhash and Gauri lived. At times Bela talked about the Peace Corps, wishing to travel to other parts of the world. After graduating she moved to Western Massachusetts, where she got a job on a farm. There she was engaged in putting in irrigation lines, weeding and harvesting, cleaning out animal pens. A series of jobs across the country became her routine. She went roaming in the enormous county, on either side of which Gauri and Subhash lived apart. She was skittish and "forged a rootless path", (225) one which seemed precarious to Subhash. "She was spending time in cities, in blighted sections of Baltimore and Detroit. She helped to convert abandoned properties into community gardens. She taught low-income families to grow vegetables in their backyards, so that they wouldn't have to depend entirely on food banks" .(224) Subhash felt a little threatened, convinced that Udayan's influence was greater and at times he believed " Udayan would come back, claiming his place, claiming Bela from the grave as his own" (225)

In the meantime, Gauri, away from Subhash and Bela, got settled in southern California, in a small college mainly meant for undergraduates. Her job was not only to teach students but also to mentor them. She was expected to be approachable and to maintain generous office hours. This obligation to be open to others and to forge alliances had in the beginning brought an unexpected strain. But she was quite successful with her colleagues and students. Yet she preferred isolation because it offered its own form of companionship:" the reliable silence of her rooms, the steadfast tranquillity of evenings" (237). When desire eventually began to push its way through, she sought friendships with men but she had never allowed herself to reach the point where they might complicate her life. In spite of her being on the guard, Lorna, a graduate student, who came to Gauri seeking an outside reader for her dissertation, unravelled her leading to the exploration of their own female bodies. Her role had changed so many times in the past: "From wife to widow, from sister-in-law to wife, from mother to childless woman... She had married Subhash, she had abandoned Bela. She had generated alternative versions of herself, she had insisted at brutal cost on these conversions. Layering her life only to strip it bare, only to be alone in the end". (240) She felt that the silence of Bela and her absence was a fitting punishment for her crime. Though late she understood what it meant to walk away from her own child.

On one Sunday, Subhash had gone to visit a small island in the middle of the swamp where the local Narragansett tribe had built a fort. During the exploration, he lost his way and did not know where he stood. Lost in thoughts, he was surprised to see a man with a familiar face approaching on a bike. It was Richard, his old apartment mate. They sat and talked for hours together and departed promising to meet at Subhash's house the next time. But after a few days, he got news from Claire, Richard's wife that Richard died of blood clot. After the funeral ceremony, Subhash happened to meet Elise Silva one of Bela's teachers at high school. He 
learnt from her that her daughter had been a member of a religious sect begun in the eighteenth century, dedicated to celibacy and simple living. Getting back home, he felt terribly alone and unable to sleep at night.

Richard's death had reinforced in Subhash's mind, the terrible need to tell Bela what she only deserved to know, which is to lay bare the story of Udayan. This, he felt, was the unfinished business of his life. Bela was now old and strong enough to handle it. Since she was all he loved, he could not muster the strength to tell it to her. Everything in Bela's life has been a reaction. It is during this time that Bela reveals that she is pregnant for more than four months. Her male companion was not a part of her life; he was simply someone Bela had known. She wanted to keep the child and become a mother. Subhash felt that hers was a version of what had brought Gauri to him years ago: "The coincidence coursed through him, numbing, bewildering. A pregnant woman, a fatherless child. Arriving in Rhode Island needing him. It was a re-enactment of Bela's life" (264) Subhash had replaced Udayan and turned into her father. Now he had prepared himself to give her back to Udayan and to risk letting her go. Summoning all the strength of his will, and abandoning everything to chance, he tells her plainly that he is only her uncle and her real father is Udayan. Initially she could not accept the information and felt the strain it sent through her body. She left the house to stay with a friend in Truro without informing Subhash. But she did call a few days later and thanked him for telling her about Udayan and said, the information helped her to clear certain things. After her daughter, Magna was born, after she became a mother, she told Subhash that it made her love him all the more, knowing the import of the sacrifice he had done for her sake.

When Magna was four, she started attending a summer programme run by the school where she would begin kindergarten in the fall. Since Magna was old enough to be apart from the mother for a time, Bela started working again in a farm. It was during this time she came into contact with a person named Drew. He was running a farm which belonged to his family. Bela began seeing him on weekends, keeping him company at an outdoor market in Bristol. He was married and divorced long ago. After a month of her regular contact with him, she introduced him to her father and to Elise. Towards the end of the summer, Drew told Bela that he wished to be a father to Magna, if Bela would allow him.

When Subhash was nearing seventy, he felt that he was entering a phase of life when anything might happen. He wanted to resolve a few things. He planned to sell his house in Tollygunge and surrender the ownership of the house in Rhode Island to Bela. He wrote a letter to Gauri asking her to sign a few papers for a divorce. Gauri had to spend many hours weighing the pros and cons, in case, she should decide on a travel to Rhode Island to give those papers personally to Subhash. It was then that she decided to attend a conference in London. And for this she arranged a connecting flight with a night's stay at an inn in Rhode Island. After imagining possible encounters with Subhash in his house, and rehearsing her possible reactions, weighing all the presumptuous chance, she walked up the path and rang the bell. It was after much hesitation that Bela opened the door. Subhash was not at home then. Bela was too overcome by mixed emotions that she was not ready to answer the questions Gauri asked her. "They were simple questions, ones that Bela did not mind answering when posed by strangers. But coming from her mother each felt outrageous. Each was an affront. She was unwilling to share with her mother, so casually, the facts and choices of her life."(309) Gauri collected bits of information from Magna about Subhash, Elise, Magna's age and her father, and so on . Gauri put the envelope of signed papers on the coffee table and slid it towards Bela. A storm was forming within Bela, before which Gauri is too puny to resist. Bela let Magna go out to collect fresh flowers for the table and shut the door. She told her mother, "How dare you set foot in this house... Go back to whatever it was that was more important... I can't stand the sight of you... Nothing will excuse what you did... You're not my mother. You're nothing... You are dead to me as he[ Udayan] is. The only difference is that you left me by choice." (312-13). Bela had never felt such violent emotion before and the force of that anger had crushed her. Even after many moments," Bela felt the urge to strike her. To be rid of her, to kill her all over again". (314) At the end of the encounter, Bela was thankful that it was she, not her father who had to confront Gauri.

Gauri was not mentally at peace to attend the conference in London. She arranged for a week's stay at Calcutta. She tried to meet Manash without success as he was away in Shillong. She visited Tollygunge, where no one recognised her and where she was once more haunted by the past images of Udayan. When she got back to California, there was a letter from Bela. The final lines of the letter posed a challenge as well as vague assurance: "You've already taught me not to need you, and I don't need to know more about Udayan. But maybe, when Meghna is older, when she and I are both ready, we can try to meet again" (325)

The final two chapters describe Subhash's second marriage to Elise Silva witnessed by a group of friends and family at a church in Rhode Island. The years the couple may live together are a shared conclusion 
to lives separately built and lived. The book ends with the narrator's description of the end of Udayan, complimenting all that went before, once again telling the reader that it was the painful and unreconciled presence of long gone Udayan's life which dictated reactions in both those closely associated with him in his life and those connected to him through lineaments of heredity. The ever present memory of Udayan has haunted Subhash and Gauri to the extent that it influenced the course of their lives and the chain of events that happened after that, against the backdrop of a changing India and America. The plot of the novel concerns, obligations and passions, parental love and abandonment, choices that we make and the blood and genetics that run in our blood, and the destiny that we cannot shake. The novel explores lives across India and America, in a span of 50 years, taking the narration style of flipping between two different geographical locations and the past and the present.

\section{Characterisation}

The characters have been so distinctively etched and brought to life with varying shades and nuances, including their own vulnerabilities. Though the vulnerability of each of the characters adds to the tragedy of the book, these give rise to the latent powers within them: Subhash's disdain for ideological revolution, Gauri's struggle with love and expression of identity, Udayan's staunch belief in 'the revolution', Bela's individuality and acceptance of reality, Meghna's innocence. All these characters appear so unique, but they are intelligently interwoven to construct a well wrought plot.These same characters can be looked at from various angles: the elder son Subhash, studious and not very brave, his younger brother Udayan, who is tougher than Subhash and takes to the path of revolution, Udayan's girlfriend Gauri, who later becomes his wife, Subhash's and Udayan's parents, Bela, born of Udayan's love for Gauri, but brought up by Subhash who marries Gauri after Udayan is killed by the police and finally Bela's daughter Meghna. There are a few more American spouses and lovers, like Holly, Elise, Lorna and Drew, but they don't really matter. The different phases of life these characters go through, perhaps, strike a chord with Haruki Murakami's Norwegian Wood (2000). In ways similar to Murakami's novel, Subhash and Gauri can be compared to Toru and Naoko, where in each case a turning point is marked by the tragic death of someone they love. Similar to the consequential readjustment of life to include Udayan's death as a referral point for many of the actions and decisions of Gauri and Subhash, Murakami's Toru begins to adapt to campus life and the loneliness and isolation he faces there, but Naoko finds the pressures and responsibilities of life unbearable.

While all other characters in The Lowland follow a predictable path, it is Gauri who comes across as the most complex, unpredictable character whose thoughts and feelings are opaque from all - even from her own daughter, Bela. Udayan's death has changed her, and after remarrying Subhash, there come a point where she wants to tell him that he is in a way better a person than his brother ever was, a thought that decodes itself gradually by the end. Her inner turbulence never comes to rest. On the other hand, there is a predictable continuity that we observe in the bond between Subhash and Udayan, which is beautifully described right from the time when they were children sneaking away to Tollygunge Club, to the time when they pursue their studies in separate nations only to converse via letters.

In her 2003 novel, The Namesake, as in her two collections of short stories - Unaccustomed Earth and Interpreter of Maladies, the lives of Lahiri's characters were made palpably real to the readers, through her exacting evocation of their day-to-day routines: the Wonder Bread sandwiches, tinted green with curry, that a Bengali mother makes for her embarrassed daughter to take to school, the careful adoption of American rituals like making snowmen or dyeing Easter eggs. Such particulars accentuated the differences between immigrant parents and their American-born children, and the almost existential sense of dislocation that exile can produce in people who feel at home neither in their ancestral country nor in the United States.

While the reader has come to know these earlier people as distinct individuals, the characters in The Lowland seem to have been conceived as representative types with designated roles to play in a family melodrama constructed to underscore generational patterns of resentment and redemption, rootedness and freedom. Udayan is the rebellious, impulsive brother, who makes a series of reckless decisions that will affect everyone who loves him for decades to come. Subhash is the nice, rational brother, who will spend much of his life dealing with the fallout from his sibling's heedless actions. Gauri is an angry, selfish woman, who will repay Subhash's generosity and kindness - and his efforts to invent a new life for them in Rhode Island — with chilly disregard.

The great ancient debate whether character is destiny or destiny, character, is once more re-enacted in favour of the former in the novel. Subhash, the more passive and conventional and drawn to nature, becomes a scientist, moving to America to pursue his oceanographic studies in Rhode Island. Udayan ,his fiery opposite, a dynamic idealist whose social conscience propels him into the Naxalite movement, the Maoist insurgency that arose out of the brutal oppression of peasants in the Naxalbari district of Darjeeling. From speeches and leaflets he progresses to knives and bombs, and is forced into hiding after his involvement in the killing of a policeman. The book is about the consequences of each of their choices. For instance, some of the strangeness felt by Gauri, 
Subhash and others is a result of certain choices they opted for in life: the decision to fight for political rights; the decision to honour the family; the decision to create an alternate life for oneself, regardless of the consequences. One reads and absorbs these choices, these consequences, a familiar enough theme in literature. But Lahiri changes it, revealing at the very end so many of the factors affecting those choices, causing the reader to face the stark emotional terrain of death and love and loss

Though initially the reader perceives Bijoli's prophecy that Gauri would never love Subhash, as being delivered by a woman embittered by the death of her favourite son, it will turn out to be all too true: Gauri will abandon her daughter, Bela - conceived with Udayan and brought up by Subhash as his own beloved child to pursue her own dreams of studying philosophy and building an academic career. Lahiri never manages to make this terrible act - handled by Gauri with cruelty and arbitrary highhandedness - plausible, understandable or viscerally felt. Why would Gauri regard motherhood and career as an either/or choice? Why make no effort to stay in touch with Bela or explain her decision to move to California? Why not discuss her need to leave her marriage and her child with her husband? One thing that strikes any reader is of Lahiri's courage to write about a mother who is incapable of loving her own children, whose maternal instinct is not an instinct but an attempt, whose priority is in intellectual pursuit but not child bearing. It breaks the mould of a stereotype image of a loving mother. She is with Bela and yet not with her at all. She was supposed to have put her as her first priority but she wouldn't.

When a writer takes on the "bad mother" (not the dominating or disapproving mother, which are common enough, but the mother who doesn't instantly and instinctively put motherhood and her children first above all things), she becomes powerful because she is such a charged figure in our current culture. But Lahiri's take ends up being not particularly nuanced or interesting - she's rather punishing and uncompromising with Gauri, and that story is as old as the hills. Because Lahiri never gives us real insight into Gauri's decisionmaking or psychology, she comes across not as a flawed and complicated person, but as a folk tale parody of a cold, selfish witch, who is fulfilling her nasty mother-in-law's worst predictions. The reader often has the sense that Lahiri is trying to fit her characters into a predetermined narrative design, which can make for diagrammatic and unsatisfying storytelling.

Gauri's situation can be grasped by just concentrating on the few moments before Udayan's death. As we have already seen, when Udayan's involvement in the movement deepens, the authorities come looking for him at his parents' home. In the following excerpt from the book, a soldier demands that Gauri tell him where her husband is hiding:

"We think he might be hiding in the water", the soldier continued, not removing his eyes from her.

"No", she said to herself. She heard the word in her head. But then she realized that her mouth was open, like an idiot's. Had she said something? Whispered it? She could not be sure.

"What did you say?"

"I said nothing."

The tip of the gun was still steady at her throat. But suddenly it was removed, the officer tipping his head toward the lowland, stepping away.

"He's there", he told the others. (103)

Lahiri asserts that the character of Gauri was the key to her exploration of how these events haunt and shape her other characters for the rest of their lives. "I wanted to understand what it might have been like to witness something like that, and what the consequences would be of witnessing something like that ...I mean, she's a 23year-old woman. She's in love with her revolutionary husband. She watches him shot in cold blood. She discovers after the fact that she is carrying his child. How does one move on from that?" (Neary) Much of the book takes place in the aftermath of that night.

Lahiri's characters in The Lowland are represented as people who apparently have their own reasons to live and die for. If Udayan has sacrificed his life for a socio-political cause, Subhash lives out a sacrifice to hold together a family before it is crushed to the point of annihilation. Readers consider Subhash as a character with a principle. $\mathrm{He}$, as a responsible elder brother, who had been studying chemical oceanography in the foreign soils of America, returns hoping to pick up the pieces of a shattered family and to heal the wounds Udayan left behind -including those seared in the heart of his brother's wife. Knowing that Gauri will essentially be alone, he decides to rescue his brother's widow from a grim future as a begrudged member of his parents' household and from her own diminished future as a daughter-in-law, by marrying her and bringing her back to the States. Gauri is pregnant with Udayan's child, but Subhash is willing to pretend to be the baby's father when they get to America so that she may have a safer, more economically secure life. Subhash proposes to Gauri by stressing the practicalities of their union: he woos her by saying; in America she could pursue her studies in philosophy. But his unspoken words are those of a lovesick poet: "[Subhash] had tried to deny the attraction he felt for Gauri. But it was like the light of the fireflies that swam up to the house at night, random points that surrounded 
him, that glowed and then receded without a trail." (116) Subhash's mother had tried to dissuade him from marrying Gauri, telling him that she's "Udayan's wife, she'll never love you." She also warned him that Gauri was "too withdrawn, too aloof to be a mother."(114) Thus Subhash ended up living a proxy life, responsibly stepping up to assume all the roles designated for his brother. And Gauri agrees to go along with the plan. She isn't in love with Subhash, but she appreciates his kindness, and they set off for the new world with modest hopes for the future. Hastily enough, the two are shown raising Gauri's daughter in America, but the memory of Udayan, his fierce politics and his terrible death have corrosive after-effects.

To grasp the predicament of Gauri and Subhash, it is important to analyse the sense of isolation they experience in a new country. This feeling of estrangement is intensified by their own awareness of the tumult they have left behind. "The real issue that interested me more in this book was, what it is like to have experienced life in a city where a situation, a political uprising, whatever you want to call it - attempted revolution, really, is what it was - has taken over the city, has altered life fundamentally, has created a dangerous, difficult, violent environment, has affected day-to-day life on practically every level?" Lahiri explains. "To be living with this day after day and then suddenly to be in a part of the world where it might as well not exist, because it is not on the radar of anybody you are around, and just simply the silence - I imagine for the characters, I imagine for Gauri, it was both a relief and deeply unsettling." (Neary)

Much of the novel takes place in this middle time, when Subhash and his wife and daughter live out their years far from the past. We watch the characters behave admirably, and selfishly. When one considers how Gauri experiences the early immigrant life in America, like the life journey of an Indian woman in America as depicted in The Immigrant (Kapur) it feels like déjà vu. A gradual change of shedding the saris for western clothes, taking the first step from the four walls of the house out into the world, finding solace in library and books and finally finding a way to breakout and reinvent herself. Gauri's experience follow the same vein but to a more drastic effect. We see Gauri, fold up her saris and chop her hair into a blunt modern style, attending philosophy classes in slacks, longing more and more to be lost in the ancient thoughts of others. Gauri has done an unforgiveable act that hurt the ones closest to her. Consequently, we see Bela, the child, growing up in a world full of secrets, slipping to and away and back again from her parents. At any rate, having launched Gauri on this course of action, the novel toils on through several more decades of its ramifications, chronicling Bela and Subhash's largely unhappy existence in a glum narrative of withdrawal, rejection, isolation and guilt, all done with Lahiri's usual tasteful restraint, though in this instance, even this virtue becomes problematic. One yearns for an outburst of raw, vulgar emotion.

The big themes that animated the first part give way to the not very compelling matter of the child's secret paternity, and the book's gaze narrows, disappointingly, on to the couple's glaciating marriage. Gauri steadily withdraws from Subhash, and then finds herself unable to love her child, Bela. Straying into a philosophy class on Subhash's campus, she becomes hooked on Plato and Descartes, and begins neglecting the little girl, leaving her alone in the house so as to study the heavy tomes that interest her much more than her daughter. More decisively callous actions follow, with devastating impacts on all concerned.

As a character, or as a full-on study in cruelty, Gauri might have been interesting or fascinating to follow, if there was an ounce of irony or humour in her portrayal, or of unabashed wickedness in her spirit. But her depiction is relentlessly solemn and insistently - actually infuriatingly - compassionate. While acknowledging the brutality of her deeds, Lahiri also wants to enlist our sympathy for Gauri as a person of tragic emotional integrity. She charts her lonely intellectual progress with a scrupulousness that seems intended to confer a kind of martyred dignity upon her, though it just intensifies the unpleasant effect of pious sadism that emanates from the book whenever she appears. It is interesting to retrace Gauri's path to self-discovery and emancipation from the assigned identities of bereaved widow, dutiful daughter-in-law, mere wife and mother. And at the end of the novel certainly the reader will not defend or condemn her refusal to let her life be defined by the flawed choices of the man she loved.

At one point, Bela and her father travel back to India, back to the world where Subhash was formed with his brother, to pay respects to the recently departed grandfather. Everything is new and uncomfortable to Bela, who watches enviously as her father is absorbed seamlessly back into the patterns and customs of the neighbourhood, scraping out the insides of a mango with his teeth like "nothing was unfamiliar to him". At the same time, readers are only too aware that Subhash wasn't entirely familiar as he appears to be. He had crossed the line into living in two worlds, never completely at home. It is not necessary, of course, that the circle of identity had to be a country or a village or a society or family - stepping outside your circle, outside our reality gives you wings and solutions - but the solutions and the wings are never to be allowed back in - one may step back in but one step backs in as oneself, without the fancy stuff. And then one has to forget the dream. One can only inhabit the twilight or the sunrise. Never both.

Later, when she is grown, Bela chooses to not take the path her parents did, being encased in the libraries and studies of academia. Instead she picks up the thread of revolution that undergirds the frame of her 
extended family, and becomes a quiet sort of activist, a wandering farm worker, an enigma both to all the dominant cultures in her life. While Subhash is at first concerned by how Bela "eschews the stability he had worked so hard to provide", he understands too, how it is a part of her nature, even though it is not a part of his. In the end, the relationship of the father and daughter take precedence over the story of two brothers; although they are intricately tied. But the characters remain fundamentally alone, a world which Lahiri often creates. Solitary automobiles, a small pot of water for a single cup of tea, an only child alone in her room while her mother slips further into her books. The pacing, the sparse prose, the length of time that Lahiri travels across in her book-it all adds up to a evocative, if rather humourless, portrayal of coming to terms with their sense of alienation.

In any case, what turns this novel around and ultimately seizes the reader's imagination is. Lahiri's deeply felt depiction of Subhash's relationship with Bela: his unwavering devotion to this good-hearted little girl; his bafflement as her grief over her mother's abandonment leads her to withdraw from him as well; his slow, painful efforts to rebuild a life for himself in the wake of Gauri's departure. It is in these later chapters that the cumbersome historical exposition and overarching narrative architecture fall away, and. Lahiri's most shining gifts as a writer come to the fore: her ability to conjure the daily texture of people's lives, her understanding of how their personal and cultural expectations have shaped their choices, her talent for mapping moods and inchoate emotions with pointillist precision. As this happens, the characters in The Lowland - with the qualified exception of Gauri - become fully human: driven not by one identifiable trait (like duty, anger or rebellion) but by a full spectrum of feelings, and capable not only of rage and vexation but also of forgiveness and hope. By its end, this ungainly novel reminds us of Lahiri's copious talents as a writer, however imperfectly they are employed here.

A pair of linked tragedies disrupts forever the lives of three generations. Like in The Infatuations, (2013) by Javier Marias, where several characters are unable to let go, though the response in Marias's characters is more rationalized, analyzed over and over, while in The Lowland it leaves the characters partially stunted, emotionally paralyzed and sort of vacant. There is this common empty room in their hearts that refuses to be filled. Lahiri drives this point home painfully and beautifully through actual vacated spaces: balconies, home offices, beds, chairs, etc. where the absent linger in spirit, forever haunting the ones who stayed. This is a powerful emotional depiction, and obviously a very sad one, though the readers could discern mostly hope in the final pages.

In the last act, after subjecting poor Subhash to a few more undeserved misfortunes, the book attempts a cathartic series of disclosures and partial reconciliations. Whether this succeeds will depend on how much strained emotional logic readers are willing to ignore in order to be moved and uplifted. Some readers will undoubtedly shed a tear as patient longing and stoic grief are rewarded with judiciously allotted doses of companionship and joy, while others may feel coerced, and find themselves resisting. Being lulled by the carefully constricted storyline, the reader might be unprepared for this ending. Revolution, duty, isolation, cultural confusion - none of it mattered, in the end. Jhumpa Lahiri makes an argument, through every page, that each of us, alone, are worth something, as alienated as we might feel.

The book spans over fifty years of the adults' lives, yet fails to recognise that people change as they age. We are not the same in late middle age as we were in early adulthood. We mature, we acquire wisdom of varying degrees, we gain insight into complex matters. This is the by product of enduring, surviving, aging. Lahiri was portraying her characters at a remove, an almost emotionless narrative of their lives. They don't evolve, so they don't seem real; they remain static, failing the readers in their expectation of characters ultimately gaining wisdom and a mature vision life. Anita Chaudhuri, an editor at Psychologies magazine, tweeted of the book: "One of the bravest books I've ever read, no tricks, no jokes, just life."

\section{Narrative Technique}

Told from the third-person narrator point of view, the narrative process cradles in past and present, using stoicism as the tone that embodies the coping mechanism of the characters. This is particularly needed to accompany a heartrending story without the melodramatics. The book is unique in the narration process changing from person to person in each individual chapter, presenting different people's views and perspectives. At times the narration is so distant, it is as if only the storyteller is present. Then just at the right moment, the narration gets closer, so close that reader and the character become one, readers see their point of view clearly though they may not agree with them but they certainly 'get' them. At times there is more telling than showing as years are spooled out, especially for one character, and yet it was done in an almost-forgivable Munro way.

Lahiri's previous novel, "The Namesake," which depicted the angst of a young Bengali-American named Gogol, had the virtues of a ferocious devotion to realist description, a satirical edge when probing upperclass New York pretensions, and a simple, linear plot. In The Lowland, the narrative moves back and forth through time and across the points of view of all the principal characters, but this diffusion do not appear to be in the service of formal playfulness or experimentation in the spirit of one of the many variants of modernism. 
This is a contemporary novel only in the sense that it knows the brisk economy of the screenplay, or the efficient design of an Apple product.

The one thing that truly takes this book a notch higher is Jhumpa's haunting, heartbreaking prose - the way she has gracefully styled each and every line of hers effortlessly transfering the reader from Tollygunge to America and back, every travel offering a deeper insight. The words wonderfully portray the gloomy, happy and insecure shades of the characters, all highlighting Lahiri's storytelling grandeur. Metaphors and vision that have been rendered to the seas and oceans are brilliant. Take this for instance- "rockweed with air bladders like textured orange grapes". She wraps her penetrating insights into exquisite prose embellished by figures of speech and this takes Lahiri to new heights of artistry - flawless transparency, immersive intimacy with characters and place. - which turns The Lowland into a magnificent, universal, and indelible work of literature. A few of such striking instances are described briefly below:

Speaking about the two brothers' foray into Tolly Club, the narrator loses himself in figurative language: "Subhash had never seen such grass, as uniform as a carpet, unfurled over sloping contours of earth. Undulating like dunes in a desert, or gentle dips and swells in the sea... The ground below was as smooth as a scalp... The trees threw afternoon shadows on the lawn. their smooth limbs divided when he looked up at them, like the forbidden zones of a woman's body" (6).

The holes in the golf ground were like "navels in the earth". (6)

Lying in bed in the morning, Subhash watched sunlight " flickering like a restless bird on the wall" (10)

In one of the young boys' visit to the Technicians' studio, where shooting was going on , Udayan was brave enough to ask them for autographs. Here the narrator draws the two into an interesting simile: "He was blind to self-constraints, like an animal incapable of perceiving certain colours. But Subhash strove to minimise his existence, as other animals merged with bark and blades of grass"

Describing the dahlias that grew in pots in the courtyard of their house, the narrator says, "The blooming orbs, violet and orange and pink, were sometimes tipped with white. Their vibrancy was shocking against the drab courtyard walls" (11)

The narrator describing the physical infirmity of Udayan after he was away from the family for a month says," The tremor in his fingers had gotten worse, persistent enough so that his teacup sometimes rattled on the saucer when he held it, so that it could be noticed when he buttoned his shirt or gripped a pen." (31-2)

Subhash gives a very picturesque description of the heron he saw near the salt pond in Rhode Island: "Blending into the grass was a heron, close enough for Subhash to see the amber bead of its eye, its slate-coloured body tinted with the late afternoon light. Its neck was settled into an $\mathrm{S}$, the sharp length of the bill like the brass letter opener his parents had given him when he left India." (45)

He becomes poetic when he catches the bird in flight: "It was the heron taking flight over the water, its great wings beating slowly and deliberately, looking at once encumbered and free. Its long neck was tucked in, dark legs dangling behind. Against the lowering sky the silhouette was black, the tips of its primary feathers distinct, the forked division of its toes" (45)

Throughout, Lahiri's prose hums along as efficiently as a well-tuned engine, showing us the melancholy beauty of coastal New England; the surreal perceptions of an immigrant (so that Subhash sees in the turning leaves of fall the "vivid hues of cayenne and turmeric and ginger pounded fresh every morning"); and the tension between generations, from the sense of abandonment and vulnerability felt by Bela to the terror of parenting, with its visions of failure and foreboding, faced by Subhash and Gauri.

Lahiri's use of 'time' will fascinate the reader, moving abruptly, standing still, spanning generations and decades--yet still managing to stay organic to the plot. The plot and story have so many intricacies that it is time which directs it all. As the novel elegantly slides back and forth between perspectives, time marching on and then doubling back on it, we slowly start to understand the basic ideologies that drive and fail the characters. We also notice that years, decades, generations pass, but people don't grow, change or express themselves- they just keep bitterness, love, sadness, guilt equally bottled up, and indulge in quiet renunciation (Subhash) or witchy selfishness (Gauri). There is very little dialogue, and what little there is, is served via stream of consciousness without quotation marks

\section{The Thematic Dimensions}

The Lowland is a melancholic tale narrated with restraint and distance. There are books that depict through gestures, symbolism and impeccable details, the subtlety with which people encounter life. This is one such book. Though stylistically different, parts of it remind readers of The Invisible Bridge (Orringer) that tells 
the story of a family shattered and remade in history's darkest hour. As shocking complexities, tragedies, and revelations multiply over the years, Lahiri astutely examines the psychological nuances of conviction, guilt, grief, marriage, and parenthood and delicately but firmly dissects the moral conundrums inherent in violent revolution.

As detailed in the section on Plot above, the novel depicts two young brothers - one being headstrong and the other more conscientious - growing up in the 1960s amid the lowland of Calcutta, getting into mischief that suits boys their age in the background of the partition of India which led to the division of the Bengal province and the infamous Naxalite movement in India (Maoist ideology and Marxist-Leninst politics). The readers are invited to embrace their closeness at the beginning while being uncomfortably aware of subtle hints from the third-person narrator that something is about to put a wedge between this brotherhood.

Getting ahead we see the various dimensions of the novel unfolding: we see them grow older; meet a bookish young wife who, even in the midst of conservative society, has feminist ideals and crude ambition; we are shown an obstinate and cruel mother-in-law; we are made to compare and contrast a marriage made in love and another conceived for convenience; and we see the wetlands of a Calcutta neighbourhood contrasted with the coast of Rhode Island. Soon complex strands are woven into the plot: we see intellectualism battle civil unrest; we see the living suffer and watch the dead live; we are shown the ugliness of post traumatic stress disorder; we tend to compare how one mother live with anguish, while the other live with ambivalence; we see our own skin crawl from a mother's abandonment and understand what it means to live a life of exile; we are shown what happens when people refuse to reconcile the past and how this ghost of the past ruins the lives in the present; we realise happiness is intertwined with misery and agony; and we are also made to wonder how people can be raised the same, yet lead different lives.

The first part of the book seems to be building towards a kind of grand, pincer-movement confrontation, shifting between Subhash's studious absorption in the estuaries and wildlife of Rhode Island, and Udayan's spiritedly engaged life back in India, with the double tragedy of modern life: political injustice and environmental degradation. The tempo is stately (Lahiri's art has always tended more towards steady accretion than juxtapositional speed), but there is enough going on to keep the reader's attention. The history lessons are interesting, and the science plays to Lahiri's great strength as an observer of the physical world. The muted textures of coastal and suburban New England are skilfully captured, with some characteristic flashes of eastmeets-west disjuncture by way of contrast, as when Subhash sees "vivid hues of cayenne and turmeric and ginger" in the autumn foliage. Meanwhile the brothers' private lives also seem to promise illuminating entanglements, with Udayan defying his family to marry an independently minded woman committed to his own political causes, and timid Subhash (who fully expects to go home and submit to an arranged marriage) falling for a single mother he meets on the beach. Ironically it seems like the more their lives diverge the more they overlap.

A variety of themes and sub-themes turn the novel thematically complex. Lahiri explores how love can still be constant though people's lives and thoughts become divergent. In Udayan's and Subhash's case they are tied by not just blood and their love for one another but through devotion to their parents and their shared homeland. Lahiri also explores how doing what seems like the right and honourable thing can have mixed results. As always she also delves into the clash of cultures and the expectations for men versus those for women. Another constant theme of hers is love and how it is expressed and what it means to individuals and their unique way of expressing it. Silence is important to watch for in her writing. Doing and saying nothing can be as telling as a shout or a hug. She raises the theme of brotherhood between individuals as well as countrymen and/or likeminded individuals. As others do in adulthood Udayan and Subhash realign themselves to other people and larger causes moving beyond their childhood alliance of two but the past continues to have an iron grip on them.

This novel has the sophistication of a political novel with Lahiri's objective to take on the political movement that forms the impetus for every plot line in the book. The countercultural upheavals of the '60s claimed that "the personal is political," (Hanish), but in "The Lowland," which takes its inspiration from an Indian variant of that upheaval, it is the political that is always personal. Lahiri stays away from the tempting trap of making a political point, and focuses instead on the effect the movement has on the handful of characters and their lives that form the heart of the book. Lahiri quotes what Che Guevara wrote in a last letter to his children, near the end of her book:" Remember that the revolution is the important thing, and that each one of us alone is worth nothing" (334). It is a shocking sentence, written by severe and resolute revolutionary, and the reader feels the sorrow of the intended recipients, the children of the soon-to-be-lost-forever father. By this time, at the end of the story of two brothers and the women in their lives, we are apt to spot the sorrow lurking everywhere. Revolutionary actions are born out of the pain of inequality; duty and obligation are seen as a means to transcend the chaos of life; people become inward and closed-off, unable to count their blessing still they are almost all gone. It is a novel about separate lives, coming together and crashing apart. 
This book does not primarily delve into Naxalism. The Naxalite movement of the 60s-70s is something that touches a raw nerve of almost every Calcuttan who may have lived in the city during those times. But creating a story around it with the local ecology of the area inhabited by the protagonists as the backdrop is something that only a writer like Lahiri can think of. The characters of the story start their lives' journey from 1960's. Naxalism was at its zenith during this period in West Bengal. Perhaps it was the only place in India which saw the repercussions of Naxalism at its worst. The fate of Gouri altered when she left Calcutta for America. The Naxalism rampant in the state pulled the trigger for it. Lahiri spoke about the movement, Kanu Sanyal and Charu Majumdar but not superfluously. The details are enough to get a reader acquainted with Naxalism. More of it would have puzzled them. Besides, the story does not demand Naxalism in detail. It was described to form a background and not to talk about the pros and cons of the movement. Yet it is surprising that Lahiri has just described, the struggles of the Bengali communist party, the reconciliation of politics with the realities of everyday family life, immigration and integration, grief and its effects, and the evolution of people as they grow from youth to middle age to their winters. But none of these were explored though it hints that human suffering doesn't randomly happen, but is embedded in a host of political and social structures that oppress certain groups of people more than others.

The Lowland is also a novel about the rashness of youth, as well as the hesitation and regret that can make a long life not worth living. Toward the end of The Lowland, a metaphorical monsoon finally hits, rousing Subhash out of his lifelong timidity, that mud hiding place Lahiri describes in her lyrical opening. Part of the beauty of this novel is that it is far from a foregone conclusion whether this hard rain will give Subhash new life, or drown him.

\section{Conclusion}

Lahiri's work has always seemed much more assured within the tighter confines of the short story than the novel. Her first collection, Interpreter of Maladies, displayed a high technical virtuosity while introducing readers to what has become her fictional realm: that small, claustrophobic milieu of Bengali Hindus working research and academic jobs in New England, Boston Brahmins twice over. "The Third and Final Continent," the last story in the collection - and one popular in high schools and writing programs, probably as much for reaffirming assumptions about America as a benevolent, welcoming place for immigrants as for its controlled prose - contained all the stock elements of Lahiri's repertory. It had the male Bengali immigrant working at a university, the sheltered wife who follows him abroad and the white American who, initially forbidding turns out to be a paragon of humanity. That realm of South Asian privilege took on a darker tinge in Lahiri's second collection, Unaccustomed Earth, where the veneer of professional success was shot through with alcoholism, suicidal impulses and depression, especially among the women. America, or India, or the world at large remained a backdrop, more or less faint, as the characters manoeuvred through their heavy psychological landscape, but the narrow focus rarely felt like weakness. There was too much mystery about the peripatetic characters, unfinished, contingent selves moving through stories as neatly structured as the suburban housing divisions they emerged from.

There is a superb story called "A Temporary Matter" included in Lahiri's collection Interpreter of Maladies, in which the revealing of painful secrets, following a domestic tragedy, enables a young woman to tell her husband (an ineffectual young academic like Subhash) that she is moving out. It prefigures, in miniature, the domestic plot of The Lowland, but it uses trauma and disclosure with an incomparably more subtle, liberating and regenerative power. It is well worth comparing the two to understand what Lahiri can do with some of the same materials as those she deploys, to relatively crude effect, in this novel.

If some of those strengths are present in The Lowland, they seem adrift in its larger swaths of time and space, diluted by waves of politics and history that Lahiri herself has chosen to bring in. Apart from Gauri, compellingly opaque at moments, the characters seem frozen into types - Subhash (dull but capable), Udayan (charismatic but irresponsible) and Bela (the rebel with a tattoo on her ankle and a compost bin in the backyard). Their misery, although powerfully depicted in scenes of confrontation or isolation, seems to be deeply private, personal, ultimately without reference to the ostensible political background introduced every now and then as Lahiri returns to the execution scene, playing it one way in depicting the brutality of the police and then the other in revealing Udayan's own complicity in a crime. There is mention of Marx and Adorno, of S.D.S., and of Charu Majumdar and Kanu Sanyal, the two central ideologues of the Naxalite movement. There are somewhat rote descriptions of demonstrations, political meetings and slogans on the wall, but not a single line of the Naxal poetry or songs that flared through India at the time, in numerous languages, and that formed a far more defining aspect of the movement than the badly made bombs and dense theoretical tracts mentioned in the novel.

There is a similar absence even when it comes to depicting America or contemporary India. There are passing references to the civil rights movement and the antiwar demonstrations, to organic farming and an Obama sticker, to India's vaunted new economic policies (now suddenly in trouble) and to the re-emergence of the Naxalites, now underground in the forests of central India, but these things seem to have as little to do with 
the characters as the characters have to do with them. It makes all four generations of the family appear strangely bereft, not so much upwardly mobile immigrants making it into the promised land as much as characters flailing at the boundaries of life, wanting to be let across the borders into the mysterious disquiet that afflicts so much of the rest of humanity.

Yet, The Lowland is a timeless tale of emotions, people's beliefs, their vulnerabilities, their needs and struggles all woven together and brought to life by the simplicity of expression, a fluid pace of narrative and multi-dimensional perspectives. All in all, this ambitious book warrants a serious reading, considering the economy of detailing that has been put into the narrative. The richness of the emotional complexities involved make for a rewarding reading experience. With a sweeping, addictive plot, The Lowland still peels naked the identities brother, lover, father, and mother, often with just a small, simple gesture. It challenges the politics of nationality with both pathetic desperation and revolutionary zeal. It makes you want and hope and despair with devastating stories of passion and indifference. Lahiri's sense of history and its consequences is as insightful as her grasp of the human heart. She weaves her tale with a sure hand around the threads of the two brother's intersecting lives, moving swiftly back and forth from one continent to the other and ranging across the seven decades from Subhash's birth in 1943 to the present day. It sounds epic in sweep, especially when combined with the laden, potent themes, the intertwining of politics and sexuality, the cauterizing of emotional wounds and grievances, and the repetition of places and personalities. Although it plays with secrets and emotional turning points (whether Bela will find out about her biological father, whether Udayan was a victim of police brutality or a deluded, violent man), it seems to possess no singular trajectory and no dominant idea beyond that of generational drift. Though this is an emotional book it is more balanced, less highly wrought than Interpreter of Maladies or Unaccustomed Earth.

\section{Reference:}

[1]. Driscoll, Molly."'Kite Runner' author Khaled Hosseini will release a new novel this spring", The Christian Science Monitor. November 2012. http://www.csmonitor.com/

[2]. Hanish, Carol. "The personal is political" in Shulamith Firestone and Anne Koedt's Notes From the Second Year: Women's Liberation. Radical Feminist, 1970. Print

[3]. Hosseini, Khaled. And the Mountains Echoed. New York:Riverhead Books, 2013. Print

[4]. Kapur, Manju. The Immigrant, Noida: Random House of India, 2011. Print.

[5]. Lahiri, Jhumpa. The Interpreter of Maladies. New York: Houghton Mifflin Harcourt, 1999. Print.

[6]. ...The Namesake. New York: Houghton Mifflin, 2003. Print.

[7]. ...Unaccustomed Earth. New Delhi: Bloomsbury, 2008. Print

[8]. ...The Lowland. Noida: Random House India, 2013. Print.

[9]. Mayfield, D.L. " Coming to Terms with our Alienation: A Feature Review of The Lowland," December $27,2013$. http://erb.kingdomnow.org

[10]. Marías, Javier. The Infatuations. Trans. Margaret Jull Costa. New Delhi: Penguin Books India, 2013. Print

[11]. Murakami, Haruki. Norwegian Wood. Trans.Jay Rubin. Vintage books, 2000. Print.

[12]. Neary, Lynn. "Political Violence, Uneasy Silence Echo in Lahiri's Lowland" September 2013 http://www.npr.org/

[13]. Orringer, Julie. The Invisible Bridge, New York: Random House, 2011. Print.

[14]. Shteyngart, Gary. Little Failure: A Memoir. New York: Random House, 2014. Print.

[15]. Thornton, Sharon G. Broken Yet Beloved. Chalice Press, 2002. Print. 